University of Montana

ScholarWorks at University of Montana

10-1996

\title{
Competition and Facilitation: Contrasting Effects of Artemisia Tridentata on Desert vs Montane Pines
}

\author{
Ragan M. Callaway \\ University of Montana - Missoula, Ray.Callaway@mso.umt.edu \\ EH DeLucia \\ Darrin Moore \\ University of Nevada - Reno \\ R Nowak \\ W. H. Schlesinger
}

See next page for additional authors

Follow this and additional works at: https://scholarworks.umt.edu/biosci_pubs

Part of the Biology Commons

Let us know how access to this document benefits you.

\section{Recommended Citation}

Callaway, Ragan M.; DeLucia, EH; Moore, Darrin; Nowak, R; Schlesinger, W. H.; and Moor, Brenda J., "Competition and Facilitation: Contrasting Effects of Artemisia Tridentata on Desert vs Montane Pines" (1996). Biological Sciences Faculty Publications. 56.

https://scholarworks.umt.edu/biosci_pubs/56

This Article is brought to you for free and open access by the Biological Sciences at ScholarWorks at University of Montana. It has been accepted for inclusion in Biological Sciences Faculty Publications by an authorized administrator of ScholarWorks at University of Montana. For more information, please contact scholarworks@mso.umt.edu. 


\section{Authors}

Ragan M. Callaway, EH DeLucia, Darrin Moore, R Nowak, W. H. Schlesinger, and Brenda J. Moor 


\title{
E2 \\ Promoting the Science of Ecology
}

\author{
Competition and Facilitation: Contrasting Effects of Artemisia Tridentata on Desert vs. \\ Montane Pines \\ Author(s): Ragan M. Callaway, Evan H. DeLucia, Darrin Moore, Robert Nowak, William H. \\ Schlesinger \\ Source: Ecology, Vol. 77, No. 7 (Oct., 1996), pp. 2130-2141 \\ Published by: Ecological Society of America \\ Stable URL: http://www.jstor.org/stable/2265707 \\ Accessed: $15 / 01 / 2009$ 23:11
}

Your use of the JSTOR archive indicates your acceptance of JSTOR's Terms and Conditions of Use, available at http://www.jstor.org/page/info/about/policies/terms.jsp. JSTOR's Terms and Conditions of Use provides, in part, that unless you have obtained prior permission, you may not download an entire issue of a journal or multiple copies of articles, and you may use content in the JSTOR archive only for your personal, non-commercial use.

Please contact the publisher regarding any further use of this work. Publisher contact information may be obtained at http://www.jstor.org/action/showPublisher?publisherCode=esa.

Each copy of any part of a JSTOR transmission must contain the same copyright notice that appears on the screen or printed page of such transmission.

JSTOR is a not-for-profit organization founded in 1995 to build trusted digital archives for scholarship. We work with the scholarly community to preserve their work and the materials they rely upon, and to build a common research platform that promotes the discovery and use of these resources. For more information about JSTOR, please contact support@jstor.org. 


\title{
COMPETITION AND FACILITATION: CONTRASTING EFFECTS OF ARTEMISIA TRIDENTATA ON DESERT VS. MONTANE PINES ${ }^{1}$
}

\author{
RaGan M. CALlaWAY \\ Division of Biological Sciences, University of Montana, Missoula, Montana 59812 USA \\ Evan H. DeLucia \\ Plant Biology, University of Illinois, Urbana, Illinois 61801 USA \\ DARRIN MOORE AND RoBERT NOWAK \\ Environmental and Resource Sciences, University of Nevada, Reno, Nevada 89557 USA
}

William H. SCHLESINGER

Departments of Botany and Geology, Duke University, Durham, North Carolina 27708 USA

\begin{abstract}
Circumstantial evidence suggests that Artemisia tridentata may out-compete Pinus ponderosa and $P$. jefferyi for water at ecotones between shrub steppe and montane forest vegetation in the Great Basin. Other studies indicate that within the shrub steppe Artemisia may act as a nurse plant for a third species of pine, P. monophylla. We used field experiments to study these contrasting effects of Artemisia on $P$. ponderos $a$ and $P$. monophylla within the context of the distributional patterns in western Nevada of all three species on andesite, and on sites where hydrothermal activity has altered the andesite. At intermediate elevations in the Great Basin Artemisia and $P$. monophylla are restricted to unaltered desert soils, whereas $P$. ponderosa is restricted to acidic, nutrient-poor altered andesite. Although-mature $P$. monophylla were virtually absent in our study plots on altered andesite, first- and second-year seedlings were common. On adjacent unaltered andesite, all size classes of $P$. monophylla occurred, and $P$. monophylla seedlings were associated with Artemisia shrubs. Pinus ponderosa and $P$. jefferyi adults and seedlings were rare on unaltered andesite, but a wide range of size classes was found on altered andesite. In experiments, all $P$. ponderosa seedlings on unaltered andesite were consumed by predators regardless of positive or negative spatial association with shrubs. Of the $P$. monophylla seedlings that germinated on unaltered andesite, all that were under shrubs survived, but only $6 \%$ of those that germinated in the intershrub spaces survived. On the open altered andesite the mortality of $P$. monophylla seedlings due to abiotic stress was high, with a final survival of only $3 \%$, whereas $28 \%$ of $P$. ponderosa seedlings survived the first growing season on altered andesite. On unaltered andesite, survival and conductance of $P$. ponderosa saplings was enhanced by shrub removal, but $P$. monophylla survival was significantly higher under shrubs than in shrub-removal plots or in intershrub spaces. In Artemisiaremoval experiments, we found that Artemisia competed with $P$. ponderosa seedlings and saplings for water. Removal of Artemisia decreased water use efficiency (WUE) of $P$. monophylla seedlings. The absence of Artemisia may restrict Pinus monophylla from outcrops of altered andesite in the Great Basin, but provide refuges for $P$. ponderosa.
\end{abstract}

Key words: altered andesite; Artemisia tridentata; competition; facilitation; field experiments; gas exchange; Great Basin Desert; interference; Pinus ponderosa; Pinus monophylla; plant interactions.

\section{INTRODUCTION}

The relative importance of interference vs. facilitation within a plant community appears to be speciesspecific as individuals may compete with some neighbors and facilitate others (Silander and Antonovics 1982, Callaway et al. 1991, 1994, Bertness and Shumway 1993, Bertness and Callaway 1994). By studying the mechanisms that regulate differences in interactions among similar species, and that might control shifts between facilitation and competition, we may gain a

\footnotetext{
${ }^{1}$ Manuscript received 2 February 1995; revised 30 September 1995; accepted 7 October 1995; final version received 17 January 1995.
}

better understanding of how complex interactions affect plant community structure and dynamics.

In the Great Basin and eastern Sierra Nevada, Artemisia tridentata Nutt. (Great Basin sagebrush) appears to differ in its effects on two associated pine species, Pinus ponderosa Laws. (ponderosa pine) and $P$. monophylla Torr. \& Frém. (single-needled pinyon pine), which have similar leaf-level physiological characteristics, water relations, and nutrient requirements (DeLucia et al. 1988, 1989, DeLucia and Heckathorn 1989, Schlesinger et al. 1989). This system provides a unique opportunity to study complex interactions and the mechanisms behind them because the communities are simple, and a single dominant species (A. triden- 
tata) appears to have contrasting effects on two congeners.

Evidence for competition between Artemisia and $P$. ponderosa comes from ecophysiological studies on adjacent but distinctly different soil types. DeLucia et al. (1988) compared daily and seasonal patterns of water use of Artemisia and $P$. ponderosa and hypothesized that profligate use of soil water by Artemisia at low soil water potentials competitively excluded the more water-conservative $P$. ponderosa from the nutrient-rich soils on which Artemisia could grow, and restricted the distribution of $P$. ponderosa to nutrient-poor outcrops in the Great Basin. In contrast, positive spatial associations between Artemisia and P. monophylla have been documented, which suggests that Artemisia may act as nurse plants for P. monophylla (Phillips 1909, Everett et al. 1983) as well as the related $P$. edulis Engelm. (two-needled pinyon [Weldon et al. 1990]). Neither competition nor facilitation between Artemisia and associated pines has been studied with manipulative field experiments. The geographic distributions of Artemisia tridentata, $P$. ponderosa, and $P$. monophylla overlap in the northeastern Great Basin, which provides an opportunity to experimentally investigate the effects of Artemisia on these pines and the importance of facilitation and competition as determinants of community structure. "Islands" of Sierran pines, including $P$. ponderosa, occur on outcrops of nutrient-poor sites created by local hydrothermal activity thought to have commenced during the Miocene (Gianella 1936, Hutsinpiller 1988). These islands are virtually devoid of Artemisia and rarely occupied by $P$. monophylla (Billings 1950, DeLucia et al. 1988, Schlesinger et al. 1989). Outcrops of altered andesite are surrounded by typical desert soils with Great Basin shrub communities dominated by Artemisia and often including P. monophylla. The ecotone between these two communities is sharp, with complete turnover of these species occurring within $\approx 5 \mathrm{~m}$. Greenhouse experiments show that Artemisia cannot grow on altered andesite because of nutrient limitations; however, contrasting with its field distributions, $P$. monophylla grows as well on soils derived from altered andesite as on typical desert soils (DeLucia et al. 1989). Considered together, this information suggests that the absence of Artemisia on altered andesite may create refuges for $P$. ponderosa because of reduced competition, but create unfavorable habitat lacking the biotic safe-sites required by $P$. monophylla.

We hypothesized that (1) Artemisia affects the community structure of these Great Basin habitats by limiting the distribution of $P$. ponderosa to altered andesite via competitive interactions, (2) Artemisia promotes $P$. monophylla on typical desert soils via facilitative interactions, and (3) the absence of Artemisia prevents $P$. monophylla from occupying altered andesite. We investigated these general hypotheses by quantifying natural spatial patterns of pine seedlings and adults and by comparing survival, growth, and gas exchange of pine seedlings in shrub-removal experiments.

\section{METHODS}

\section{Species distributions on and off altered andesite}

We used two approaches to measure species distributions. For this part of the study Pinus ponderosa and $P$. jefferyi were recorded as "yellow pines" because seedlings of the two species were indistinguishable in the field. Only $P$. ponderosa was used throughout the rest of the study. First, we analyzed data collected in May 1986 at five sites near Reno, Nevada, described by Billings (1950) and DeLucia et al. (1988) where $P$. monophylla was a major component of the vegetation. Pine seedling and shrub densities were measured, at each of the sites, in $502 \times 2 \mathrm{~m}$ plots on altered andesite and $502 \times 2 \mathrm{~m}$ plots on unaltered andesite. Adult pine densities were measured at each site in one 0.1 -ha plot on altered andesite and one 0.1-ha plot on unaltered andesite. We used separate two-way contingency analyses (df $=1$; SYSTAT, Wilkinson 1990) for each species to test for differences in seedling and adult ratios between altered and unaltered andesite. Yellow pines were tested as a group and sites were pooled.

For our second approach, we measured densities of Artemisia, $P$. monophylla, and the yellow pines ( $P$. ponderosa $+P$. jefferyi $)$; size classes of the pines; and spatial associations between pine seedlings and Artemisia at the Virginia Mountains site, $20 \mathrm{~km}$ southwest of Reno, Nevada, in August 1993. We measured species distributions and interspecific associations along 50-m transects on north- and south-facing slopes. On each aspect, 10 transects were located on altered andesite and 10 on unaltered andesite. Point-centered quarter sampling (Cottam and Curtis 1956) was used at 10 random points on each transect. Densities were calculated for shrubs and pine seedlings $(<0.5 \mathrm{~cm}$ stem diameter at ground level), saplings $(0.5-5.0 \mathrm{~cm}$ stem diameter at ground level), and mature individuals ( $>5$ $\mathrm{cm}$ stem diameter at ground level) of $P$. ponderos $a$ and $P$. monophylla. All pine seedlings were recorded as either under the canopy of a shrub or in the open. Projected ground areas covered by each individual shrub and $P$. monophylla were estimated from two measurements of canopy diameter for each shrub and tree recorded on the transect and used to estimate total shrub cover on altered and unaltered andesite. Observed shrub-seedling association was tested against expected with chi-square tests.

\section{Germination and seedling survival of planted seeds}

To study the fate of $P$. ponderosa and $P$. monophylla seeds and seedlings on altered and unaltered andesite, we buried 510 seeds of each species in each soil type. Single seeds were planted $2-3 \mathrm{~cm}$ deep at $1-\mathrm{m}$ intervals on permanent transects in November 1992 at the Desert Research Institute (DRI) and Peavine sites (see site 
TABLE 1. Densities (individuals/ha) of pines and dominant shrubs on hydrothermally altered and unaltered andesite in five sites in the eastern Sierra Nevada and adjacent Great Basin. Two-way contingency analysis showed no significant difference between substrates in the ratios of seedlings and adults of yellow pines pooled across sites $(G=3.5$, df $=12, P=0.06)$.

\begin{tabular}{|c|c|c|c|c|c|c|c|}
\hline \multirow[b]{3}{*}{ Site } & \multirow[b]{3}{*}{ Alt. (m) } & \multicolumn{4}{|c|}{ Yellow pines $\dagger$} & \multirow{2}{*}{\multicolumn{2}{|c|}{$\frac{\text { Pinus monophylla }}{\text { Altered andesite }}$}} \\
\hline & & \multicolumn{2}{|c|}{ Altered andesite } & \multicolumn{2}{|c|}{ Unaltered andesite } & & \\
\hline & & Adult & Seedling & Adult & Seedling & Adult & Seedling \\
\hline Virginia Mts. & 1540 & 100 & 750 & 0 & 0 & 10 & 400 \\
\hline Virginia Mts. & 1645 & 60 & 50 & 0 & 0 & 0 & 250 \\
\hline Alpine County & 1830 & 20 & 50 & 30 & 0 & 20 & 0 \\
\hline Virginia Mts. & 1830 & 90 & 1000 & 0 & 0 & 10 & 2750 \\
\hline Alpine County & 1920 & 70 & 1150 & 0 & 100 & 0 & 400 \\
\hline Mean and 1 SE & & $82 \pm 18$ & $817 \pm 289$ & $5 \pm 5$ & $17 \pm 17$ & $12 \pm 5$ & $658 \pm 423$ \\
\hline
\end{tabular}

$\dagger$ Pinus ponderosa and P. jefferyi.

$\ddagger$ Ribes velutinum dominant.

I| Purshia tridentata dominant, otherwise Artemisia tridentata is only species recorded.

descriptions in DeLucia et al. 1988, Schlesinger et al. 1989, Callaway et al. 1994). The transects were randomly located and equal numbers of seeds were planted at each site. Because these sites are close to each other and similar topographically we analyzed the pooled results with a chi-square test using one degree of freedom. Seeds were recorded as either under shrubs or in the open. To facilitate the relocation of the seeds they were buried directly on top of $1 \times 1 \mathrm{~cm}$ steel markers. Transects were surveyed in May, June, and September 1993 for seedlings, and in September all planting sites were excavated. If markers were present without seeds, we presumed the seed to have been removed by predators. If no seedling, seed, or marker could be found at a particular planting location, that replicate was not included in the analyses of seed fates because we were uncertain of relocating the position accurately. Analysis of seedling germination (presence of shoot in May) was based on all 510 sites where seeds had been planted. For each census period, pine seedlings were recorded as living, present but dead, or missing. We often found chewed stems or cut shoots at sites where seedlings had disappeared, which suggested that missing seedlings were removed by predators.

\section{Survival and growth of planted seedlings in shrub- removal experiments on unaltered andesite}

To examine the effects of shrubs on soil moisture availability and the survival and growth of pine seedlings, we transplanted 40 four-month-old seedlings of each pine species into each of three treatments in $\mathrm{Ar}$ temisia-dominated vegetation on unaltered andesite on 10 May 1992 at the DRI site. Pinus ponderosa and $P$. monophylla seeds were collected in northwestern $\mathrm{Ne}$ vada, and seedlings were grown in greenhouses for 3 mo. Before planting in the field the seedlings were left outside to acclimate to the natural climate. Seedlings were planted in the following experimental treatments: (1) under Artemisia shrubs; (2) in intershrub spaces; (3) plots from which all shrubs had been removed by hand between 5 and 8 May 1992. Seedlings were plant- ed in holes $20 \mathrm{~cm}$ deep and initially given $1 \mathrm{~L}$ of water each. Three days after planting all seedlings received another $1 \mathrm{~L}$ of water. Treatments were established within 10 randomly located blocks at the DRI site. Each block consisted of a $10 \times 20 \mathrm{~m}$ shrub-removal plot, a contiguous $10 \times 20 \mathrm{~m}$ plot in which pine seedlings were planted under Artemisia, and a third contiguous $10 \times 20 \mathrm{~m}$ plot in which pine seedlings were planted in the intershrub spaces. Treatment plots were located randomly within a block and four seedlings of each species were alternately planted at 2-m intervals on a transect through the middle of each plot. Seedling survival was censused periodically from May through September 1992, after which surviving seedlings were harvested, measured for leaf area, dried at $60^{\circ} \mathrm{C}$, and weighed. Block, treatment, and species differences in survival, leaf area, and shoot mass were tested with three-way ANOVA (Wilkinson 1990).

Soil moisture was measured every $3 \mathrm{~d}$ between 11 May and 23 May with a Campbell-Pacific Model 503 neutron moisture probe that was fitted with an adapter for surface sampling $(\approx 0-20 \mathrm{~cm}$ depth$)$ and calibrated with gravimetric soil samples. Neutron probe measurements were taken for $30 \mathrm{~s}$ at three locations in each plot that were $\geq 1 \mathrm{~m}$ from the watered seedlings and that represented the treatments in each plot. Samples in the shrub-removal treatment were randomly located. Only trace amounts of rainfall were recorded during our sample period. The three measurements taken on each day were averaged and differences in soil moisture over time were tested with two-way (day $\times$ treatment) repeated-measures ANOVA, and with one-way ANOVA at each date (Systat 1990).

\section{Gas exchange of planted seedlings in shrub-removal experiments on unaltered andesite}

We measured daily patterns of photosynthesis and conductance of five randomly chosen seedlings of each species in each of the three treatments in two adjacent blocks on 27 and 28 May 1992 with a LI-COR 6200 infrared gas-analysis system. Gas exchange was mea- 
In contrast, ratios of seedlings to adults differed significantly between sites for Pinus monophylla $(G=363.9$, df $=12, P<0.0001$ ).

\begin{tabular}{|c|c|c|c|}
\hline \multirow{2}{*}{\multicolumn{2}{|c|}{ Pinus monophylla }} & \multicolumn{2}{|c|}{ Artemisia tridentata } \\
\hline & & \multirow{2}{*}{$\begin{array}{r}\text { Altered } \\
\text { andesite } \\
\end{array}$} & \multirow{2}{*}{$\begin{array}{c}\text { Unaltered } \\
\text { andesite }\end{array}$} \\
\hline \multicolumn{2}{|c|}{ Unaltered andesite } & & \\
\hline Adult & Seedling & Adult & Adult \\
\hline 20 & 0 & 0 & 4200 \\
\hline 30 & 0 & 0 & 2300 \\
\hline 20 & 50 & 0 & 5600 \\
\hline 860 & 450 & 0 & 1400 \\
\hline 100 & 200 & 0 & $3650 \S$ \\
\hline $313 \pm 169$ & $483 \pm 350$ & 0 & $3791 \pm 699$ \\
\hline
\end{tabular}

sured on whole-seedling shoots in a custom-designed 1.2-L cuvette. Fan speed in the cuvette was adjusted to create a boundary-layer resistance of $\approx 20.0 \mathrm{~s} / \mathrm{m}$ (see Smith 1980). Measurements of ambient humidity and leaf temperature were taken prior to each measurement of gas exchange on leaves immediately prior to enclosure in the cuvette and subsequently used to estimate transpiration (Pearcy et al. 1992). Water-use efficiency (WUE) was calculated as $\mathrm{CO}_{2}$ uptake (in moles) divided by $\mathrm{H}_{2} \mathrm{O}$ transpired (in moles). Both days were cloudless and similar in temperature and humidity; thus, we combined measurements from both days for a given species and treatment to increase sample sizes.

- To compare daily patterns of gas exchange among species and treatments, the 10-12 diurnal measurements for each individual seedling were fitted to a fourthorder regression curve and the areas under the curve were integrated. These integrated daily gas-exchange rates were statistically analyzed with two-way (species by treatment) ANOVA. Because our sample sizes were limited, we did not include block effects in the ANOVA; however, we expected the block effects to be small because the blocks were within $20 \mathrm{~m}$ of each other on the same north-facing slope.

\section{Survival and leaf conductance of $\mathrm{P}$. ponderosa in shrub-removal experiments}

Because of high losses of 4-mo-old $P$. ponderosa seedlings in the 1992 experiment, apparently due to predation, we could not compare physiological responses or growth in treatments over the whole growing season. To redress this problem, in May 1993 we planted 40 two-year-old $P$. ponderosa saplings in each of the three treatments in the same 10 blocks used for the 1992 experiment. Shrub regrowth was removed. These saplings were planted and initially watered as were the seedlings, then censused every week during the summer. Conductance was measured with a LICOR 1600 steady-state porometer every $2 \mathrm{wk}$, between 0800 and 1030, from 16 June to 7 September, on all living saplings in each treatment in three of the blocks. Different saplings were measured during each sampling period, but because of mortality, less than five saplings remained for open and under-shrub treatments in the later weeks.

Young $P$. ponderosa were rare on unaltered andesite; however, we located 14 saplings, ranging from 3.2 to $11.7 \mathrm{~cm}$ stem diameter at ground level, intermixed with Artemisia on unaltered andesite at the Peavine site. These saplings were grouped into seven pairs of similar-sized plants and used in a third shrub-removal experiment. All shrubs were removed within a radius of $1 \mathrm{~m}$ around one randomly chosen member of each pair in September 1992. Beginning the following spring, conductance was measured between 0900 and 1100 on three different fascicles on the east-facing side of each sapling, and recorded as the mean of the three fascicles. Measurements were made every $2 \mathrm{wk}$ from 20 May to 9 September 1993.

\section{Survival of naturally occurring P. monophylla seedlings with imitation nurse plants on altered andesite}

To test the potential importance of Artemisia nurse plants in the survival of $P$. monophylla seedlings on altered andesite, we conducted field experiments with "imitation" nurse shrubs in the Virginia Mountains. In August 1993, we sheltered 25 natural first-year P. monophylla seedlings on a north-facing slope and 20 firstyear seedlings on a south-facing slope with imitation nurse plants and compared their survival to paired firstyear seedlings without imitation nurse plants. To imitate nurse plants, we cut branches from Artemisia shrubs, sprayed the leaves with lacquer to promote leaf retention, and staked the branches into the soil so that they sheltered the $P$. monophylla seedlings. Mimic nurse plants were located so that small branches sheltered $P$. monophylla seedlings from above and on three sides. Seedlings were censused between August 1993 and September 1994.

\section{RESUlts}

\section{Species distributions on unaltered and altered andesite}

Artemisia tridentata and other shrubs were absent from all plots located on altered andesite in all five study sites in the Sierra Nevada and the adjacent Great Basin that were sampled in 1986 (Table 1). For the five sites combined, yellow pine seedlings and adults were 48 times and 16 times more common, respectively, on altered andesite than on unaltered andesite. The ratios of seedlings to adults for yellow pines were 10:1 on altered andesite and 3.4:1 on unaltered andesite, but these ratios did not differ significantly $(G=3.5$, df $=$ $1, P=0.061)$ suggesting that seedlings had similar probabilities of becoming adults on either substrate.

Relative distributions of $P$. monophylla seedlings and adults between substrates were different than for yellow pines and indicated that $P$. monophylla ger- 
TABLE 2. Densities (individuals/ha) of dominant perennials on hydrothermally altered and unaltered andesite in the Virginia Mountains.

\begin{tabular}{lrr}
\hline \hline & $\begin{array}{r}\text { Altered } \\
\text { andesite }\end{array}$ & $\begin{array}{c}\text { Unaltered } \\
\text { andesite }\end{array}$ \\
\hline North-facing slope & & \\
Artemisia tridentata $\dagger$ & 1 & 765 \\
$P$. monophylla seedlings & 167 & 82 \\
$P$. monophylla saplings & 0 & 48 \\
Mature P. monophylla & 0 & 426 \\
Yellow pine seedlings & 36 & 0 \\
Yellow pine saplings & 17 & 0 \\
Mature yellow pines & 209 & 2 \\
South-facing slope & & \\
Artemisia tridentata & 4 & 522 \\
P. monophylla seedlings & 104 & 71 \\
P. monophylla saplings & 0 & 50 \\
Mature P. monophylla & 1 & 258 \\
Yellow pine seedlings & 24 & 0 \\
Yellow pine saplings & 9 & 0 \\
Mature yellow pines & 158 & 1 \\
\hline
\end{tabular}

$\dagger$ Artemisia tridentata constituted $>95 \%$ of the shrub density of the transects.

minated readily on altered andesite, but few seedlings survived to maturity (Table 1). Seedlings were abundant on both altered and unaltered andesite, but adults were virtually absent on soils derived from altered andesite. The ratio of seedlings to adults was $55: 1$ on altered andesite vs. 1.5:1 on unaltered andesite. Expected proportions of adult density, as predicted from seedling density, differed from the observed $(G=$ 363.9, df $=1, P<0.001)$.

On transects in the Virginia Mountains, P. monophylla seedlings were also much more abundant on altered andesite than on unaltered andesite (Table 2). In contrast, mature $P$. monophylla were virtually absent on altered andesite, but were numerous on unaltered andesite. Yellow pine seedlings were less common than those of $P$. monophylla on altered andesite, but adult $P$. ponderosa and $P$. jefferyi were abundant (Table 2 ). No yellow pine seedlings were found on transects on unaltered andesite and adult yellow pines were rare.
Both approaches showed corresponding patterns of plant distributions on altered and unaltered andesite. First, seedlings of yellow pines and $P$. monophylla were common on altered andesite, but seedlings of the latter rarely reached maturity. Second, seedlings and adults of yellow pines were virtually absent on unaltered andesite where $P$. monophylla in all size classes were abundant.

As expected from the low proportion of shrub cover, all $P$. monophylla seedlings on altered andesite were in the open. On unaltered andesite, however, $P$. monophylla seedlings had positive spatial associations with Artemisia shrubs (Table 3). On north slopes $71 \%$ of $P$. monophylla seedlings were under shrubs even though shrubs covered only $32 \%$ of the area sampled $\left(\chi^{2}=\right.$ $57.9, \mathrm{df}=2, P<0.001)$. On south-facing slopes $86 \%$ of $P$. monophylla seedlings were under shrubs which covered only $23 \%$ of the area sampled $\left(\chi^{2}=187\right.$, df $=2, P<0.001)$.

\section{Germination and seedling survival of planted seeds}

Pinus ponderosa experienced high seed predation and low germination rates on both soil types, but seedlings in the shrub matrix on unaltered andesite had a much lower probability of surviving than those on altered andesite. Because we missed events occurring prior to May, actual germination was likely to have been higher. In August, we were able to locate 211 of the $463 P$. ponderosa seed markers not associated with seedlings in May, and 110 of these were found with ungerminated seeds (Table 4). Thus we estimated seed predation for $P$. ponderosa on altered andesite at $48 \%$. Estimated seed predation rates were significantly higher on unaltered andesite than altered andesite $\left(\chi^{2}=\right.$ 18.79, df $=2, P<0.001)$ and tended to be higher under shrubs $(77 \%)$ than in intershrub spaces $(68 \%)$ on the unaltered andesite. Of the $510 P$. ponderosa seeds planted on altered andesite in November 1992, only 9\% produced seedlings that were alive in May 1993 (Table 4). Six percent of $P$. ponderos $a$ seeds germinated on unaltered andesite $\left(\chi_{\text {substrate }}^{2}=4.0, \mathrm{df}=2, P>0.05\right)$

TABLE 3. Goodness-of-fit tests for spatial associations between Pinus monophylla seedlings and Artemisia tridentata shrubs on unaltered andesite in the Virginia Mountains.

\begin{tabular}{llccc}
\hline \hline & & & \multicolumn{2}{c}{$\begin{array}{c}\text { Number of associated } \\
\text { Pinus monophylla } \\
\text { seedlings }\end{array}$} \\
\cline { 3 - 5 } $\begin{array}{c}\text { Site } \\
\text { aspect }\end{array}$ & Cover type & Relative frequency & Observed & Expected \\
\hline North & Open & 0.46 & 18 & 38 \\
& Pinus monophylla & 0.22 & 6 & 18 \\
& Artemisia tridentata & 0.32 & 58 & 26 \\
& & $n=82$ seedlings & & \\
South & Open & $57.9, P<0.001$ & 2 & 41 \\
& Pinus monophylla & 0.57 & 5 & 14 \\
& Artemisia tridentata & 0.20 & 64 & 16 \\
& & 0.23 & & \\
& & $n=71$ seedlings & & \\
& & $\chi^{2}=187.0, P<0.001$ & & \\
\end{tabular}


TABLE 4. Germination and survival of Pinus ponderosa and P. monophylla from seeds planted in November on hydrothermally altered andesite and on unaltered andesite at Desert Research Institute and Peavine Mountain.

\begin{tabular}{|c|c|c|c|c|c|c|}
\hline & \multicolumn{3}{|c|}{ Pinus ponderosa } & \multicolumn{3}{|c|}{ Pinus monophylla } \\
\hline & \multirow[b]{2}{*}{$\begin{array}{l}\text { Altered } \\
\text { andesite }\end{array}$} & \multicolumn{2}{|c|}{ Unaltered andesite } & \multirow[b]{2}{*}{$\begin{array}{l}\text { Altered } \\
\text { andesite }\end{array}$} & \multicolumn{2}{|c|}{ Unaltered andesite } \\
\hline & & $\begin{array}{l}\text { Under } \\
\text { shrub }\end{array}$ & Open & & $\begin{array}{l}\text { Under } \\
\text { shrub }\end{array}$ & Open \\
\hline No. seeds planted & 510 & 271 & 239 & 510 & 278 & 232 \\
\hline Markers located & 211 & 130 & 81 & 244 & 91 & 104 \\
\hline Seeds present & 110 & 30 & 26 & 125 & 7 & 13 \\
\hline Seed predation $(\%) \dagger$ & 48 & 77 & 68 & 49 & 92 & 87 \\
\hline \multicolumn{7}{|l|}{ Seedlings } \\
\hline May & 47 & 14 & 13 & 66 & 12 & 16 \\
\hline July & 30 & 5 & 0 & 56 & 12 & 16 \\
\hline August & 13 & 0 & 0 & 2 & 12 & 1 \\
\hline Initial germination (\%) & 9 & 6 & 5 & 13 & 5 & 6 \\
\hline Final survival (\%) & 28 & 0 & 0 & 3 & 100 & 6 \\
\hline Seedling predation $(\%) \dagger$ & 29 & 100 & 100 & 6 & 0 & 27 \\
\hline
\end{tabular}

$\dagger$ Predation of either seedlings or seeds was assumed if a previously located seedling disappeared or if a marker was located without the seed.

with similar numbers recorded under shrubs versus intershrub spaces. Twenty-eight percent of $P$. ponderosa seedlings that germinated on altered andesite in May survived until August 1993 and only 29\% of the mortality was attributed to predation; the rest dried in place. In contrast, all $P$. ponderosa seedling mortality on unaltered andesite (in Artemisia-dominated shrubland) appeared to be the result of predation.

Pinus monophylla experienced much higher seed predation and lower germination rates on unaltered andesite than on altered andesite (Table 4). However, in contrast with $P$. ponderosa, seedling survival directly under shrub canopies was higher than on the open al-

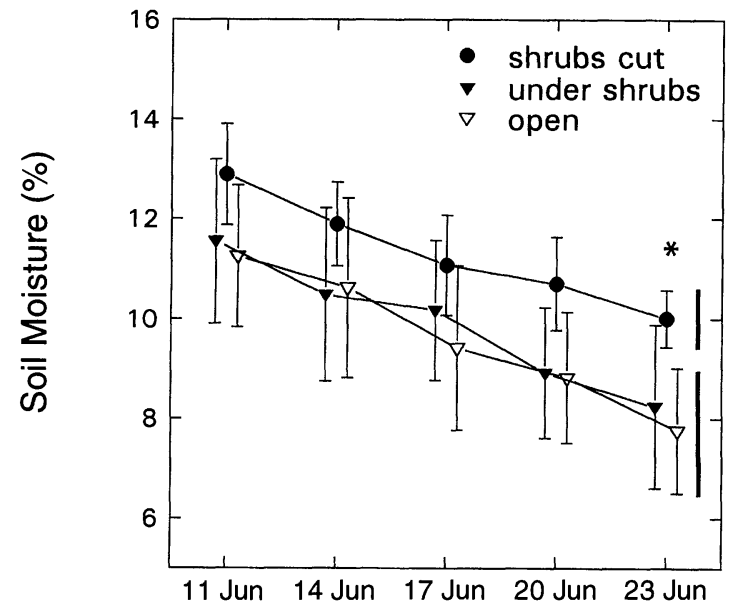

FIG. 1. Percent soil moisture in the upper $20 \mathrm{~cm}$ under shrubs, in intershrub spaces, and in shrub-removal treatments, on unaltered andesite at the Desert Research Institute. Data show means $\pm 1 \mathrm{SE} ; *$ indicates higher soil moisture in shrubremoval plots based on a pairwise (within block) Student's $t$ test. Treatments whose final means do not share a solid vertical bar (at right of data field) were significantly different as determined by repeated-measures ANOVA, $P<0.005$ ). tered andesite or in the open intershrub spaces. On altered andesite, $P$. monophylla seed predation was estimated at $49 \%$, whereas on unaltered andesite seed predation was estimated at $92 \%$ and $87 \%$ under shrubs and in the intershrub spaces, respectively $\left(\chi_{\text {microste }}^{2}=\right.$ 56.39 , df $=2, P<0.001$ ). Thirteen percent of $P$. monophylla seeds planted on altered andesite were located as seedlings in May. Of these, only 3\% survived until August on altered andesite. In contrast to P. ponderosa, a much higher proportion of the mortality on altered andesite $\left(\chi_{\text {species }}^{2}=9.78, \mathrm{df}=1, P<0.01\right)$ occurred by seedlings drying in place, which suggests that seedling success for $P$. monophylla was strongly limited by abiotic stress. On unaltered andesite, the percentage of $P$. monophylla seeds that produced seedlings on the unaltered andesite was similar to that of $P$. ponderosa, with $5 \%$ germinating under shrubs and $6 \%$ germinating in the spaces between shrubs. All P. monophylla seedlings under shrubs survived until August, in comparison to only $6 \%$ of seedlings in the intershrub spaces.

Survival, growth, and gas exchange of planted seedlings in shrub-removal experiments on unaltered andesite

Removal of shrubs resulted in significantly higher soil moisture content near the soil surface (Fig. 1, repeated-measures ANOVA, $F_{\text {treat }}=4.79$, df $=2, P=$ $0.017)$. Soil moisture in intershrub spaces was not significantly different than under shrubs.

Of the 40 four-month-old $P$. ponderos $a$ seedlings planted in each treatment in May 1992 on unaltered andesite at DRI, two survived where shrubs had been cut, one survived under Artemisia shrubs, and one survived in the intershrub spaces (Fig. 2). Ninety-two percent and $77 \%$ of $P$. ponderosa seedling mortality appeared to be due to predation in the shrub-removal treatment and intershrub spaces, respectively; however, 


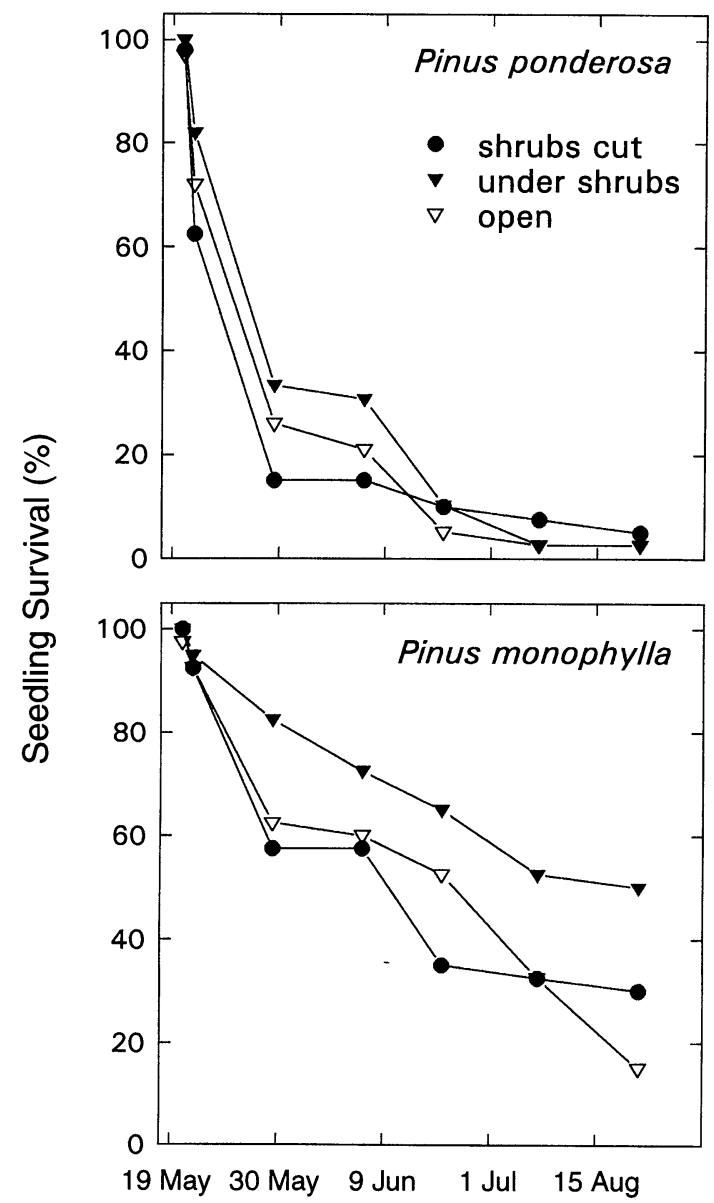

FIG. 2. Survival of 4-mo-old, planted Pinus ponderosa and Pinus monophylla seedlings on unaltered andesite under Artemisia tridentata shrubs, in the intershrub spaces, and in shrub-removal treatments. For all species and treatments, initial $n=40$ seedlings.

predation appeared to account for only $50 \%$ of mortality under shrubs (Table 5). As in the seed-planting experiment, we often observed chewed stems and cut shoots at locations where seedlings disappeared. Very low survivorship of $P$. ponderosa precluded growth analyses at the end of the growing season.

Of the $P$. monophylla seedlings planted in May, $50 \%$ survived under shrubs, $30 \%$ survived in the shrub-removal treatment, and $15 \%$ survived in the intershrub spaces (Fig. 2, two-way block $\times$ treatment ANOVA, $F_{\text {treat }}=13.73$, df $\left.=2,9, P<0.001\right)$. Predation estimates, which were much lower than for $P$. ponderosa seedlings, accounted for $68 \%$ in the shrub-removal treatment, $47 \%$ in the intershrub spaces, and $20 \%$ under shrubs (Table 5). As in the seed-planting experiment, low predation on $P$. monophylla seedlings in comparison to $P$. ponderosa seedlings suggests the former were generally less palatable. In contrast to survival, mass of seedlings that survived was highest in the cut treatment and lowest under shrubs (Table 5, two-way block $\times$ treatment ANOVA, $F_{\text {treat }}=3.806, \mathrm{df}=2,8$, $P=0.035$ ). Total leaf area was $16 \%$ higher in the shrub-removal treatment than under shrubs, but treatment effects were only marginally significant $\left(F_{\text {treat }}=\right.$ 3.302 , df $=2,8, P=0.052$. Specific leaf mass did not differ among treatments $\left(F_{\text {treat }}=2.937, \mathrm{df}=2,8, P=\right.$ 0.070).

Integrated daily transpiration rates of $P$. ponderosa in shrub-removal plots were $41 \%$ higher than rates under shrubs and $49 \%$ higher than for seedlings in intershrub spaces (two-way ANOVA, $F_{\text {treat }}=15.0, \mathrm{df}=2$, $24, P<0.001$, Table 6). Transpiration rates of $P$. monophylla seedlings were not significantly different among the three treatments (Table 6). Across all treatments, $P$. ponderosa seedlings transpired at greater rates than $P$. monophylla seedlings (two-way ANOVA, $\left.F_{\text {species }}=119.6, \mathrm{df}=1,24, P<0.001\right)$.

Whole-shoot photosynthetic rates of $P$. ponderosa were higher than for $P$. monophylla (two-way ANOVA, $F_{\text {species }}=58.0, \mathrm{df}=1,24, P<0.001$, Table 6). As found for transpiration, shrub removal elicited stronger responses from $P$. ponderosa than $P$. monophylla, the former increasing daily integrated rates of photosynthesis from $14.8 \pm 1.7$ and $12.4 \pm 1.0 \mathrm{mmol} \cdot \mathrm{g}-1 \cdot \mathrm{d}^{-1}$ (means $\pm 1 \mathrm{SE}$ ) in intershrub spaces and under shrubs, respectively, to $24.2 \pm 1.3 \mathrm{mmol} \cdot \mathrm{g}^{-1} \cdot \mathrm{d}^{-1}$ where shrubs were removed (two-way ANOVA, $F_{\text {treat }}=19.8$, df $=$ 2 , 34, $P<0.001$ ). Integrated daily PAR was $53 \%$ less under shrubs than in the open, but net carbon assimilation were similar for seedlings in these microhabitats.

Whole-shoot WUEs of $P$. ponderosa seedlings were

TABle 5. Growth and apparent cause of mortality for Pinus ponderosa and P. monophylla seedlings transplanted under shrubs, in spaces between shrubs (open), and where shrubs were removed (shrubs cut). For all species-treatment combinations, 40 seedlings were planted. Shared superscript letters indicate no significant differences within a row (post-ANOVA Tukey test).

\begin{tabular}{lcccccccc}
\hline \hline & \multicolumn{3}{c}{ Pinus ponderosa } & & \multicolumn{3}{c}{ Pinus monophylla } \\
\cline { 2 - 3 } & $\begin{array}{c}\text { Shrubs } \\
\text { cut }\end{array}$ & $\begin{array}{c}\text { Under } \\
\text { shrubs }\end{array}$ & Open & & $\begin{array}{c}\text { Shrubs } \\
\text { cut }\end{array}$ & & $\begin{array}{c}\text { Under } \\
\text { shrubs }\end{array}$ & Open \\
\hline No. seedlings surviving & 2 & 1 & 1 & & 12 & & 20 & 6 \\
Total leaf area $\left(\mathrm{cm}^{2}\right)$ & $\ldots$ & $\ldots$ & $\ldots$ & & $16.6 \pm 0.8^{\mathrm{a}}$ & & $12.8 \pm 0.9^{\mathrm{b}}$ & $14.3 \pm 1.4^{\mathrm{ab}}$ \\
Aboveground mass $(\mathrm{kg})$ & $\ldots$ & $\ldots$ & $\ldots$ & & $0.27 \pm 0.02^{\mathrm{a}}$ & & $0.20 \pm 0.02^{\mathrm{b}}$ & $0.25 \pm 0.02^{\mathrm{ab}}$ \\
Mortality due to predation $(\%) \dagger$ & 92 & 50 & 77 & & 68 & & 20 & 47 \\
\hline
\end{tabular}

$\dagger$ Predation was assumed if a previously recorded living seedling disappeared. 
TABLE 6. Means and standard errors of daily integrated transpiration, photosynthesis, and water-use efficiency (WUE) of Pinus ponderosa and P. monophylla seedlings under Artemisia tridentata shrubs, in intershrub spaces, and in shrub-removal treatments. $n=5$ saplings for all species-treatment combinations. Shared superscript letters indicate no significant differences within a column (post-ANOVA Tukey test).

\begin{tabular}{cccc}
\hline \hline & $\begin{array}{c}\text { Transpiration } \\
\left(\mathrm{mol} \cdot \mathrm{g}^{-1} \cdot \mathrm{d}^{-1}\right)\end{array}$ & $\begin{array}{c}\text { Photosynthesis } \\
\left(\mathrm{mmol} \cdot \mathrm{g}^{-1} \cdot \mathrm{d}^{-1}\right)\end{array}$ & $\begin{array}{c}\text { WUE } \\
(\mathrm{mol} / \mathrm{mol})\end{array}$ \\
\hline Pinus ponderosa & & & \\
Under shrubs & $12.8 \pm 0.9^{\mathrm{a}}$ & $14.8 \pm 1.7^{\mathrm{a}}$ & $0.00114 \pm 0.00005^{\mathrm{a}}$ \\
Open & $11.0 \pm 0.8^{\mathrm{a}}$ & $12.4 \pm 1.0^{\mathrm{a}}$ & $0.00112 \pm 0.00002^{\mathrm{a}}$ \\
Shrubs cut & $21.4 \pm 1.8^{\mathrm{b}}$ & $24.2 \pm 1.3^{\mathrm{b}}$ & $0.00116 \pm 0.00009^{\mathrm{a}}$ \\
Pinus monophylla & & & \\
Under shrubs & $5.6 \pm 0.7^{\mathrm{c}}$ & $10.2 \pm 0.9^{\mathrm{a}}$ & $0.00206 \pm 0.00021^{\mathrm{ac}}$ \\
Open & $4.8 \pm 0.3^{\mathrm{c}}$ & $9.1 \pm 0.8^{\mathrm{a}}$ & $0.00196 \pm 0.00026^{\mathrm{bc}}$ \\
Shrubs cut & $7.2 \pm 1.1^{\mathrm{c}}$ & $10.1 \pm 0.8^{\mathrm{e}}$ & $0.00147 \pm 0.00011^{\mathrm{b}}$ \\
\hline
\end{tabular}

also similar among treatments (Table 6, two-way ANOVA, $\mathrm{F}_{\text {treat }}=2.3$, df $\left.=2,24, \mathrm{P}=0.126\right)$. WUEs of $P$. monophylla were 0.001 to $0.002 \mathrm{~mol} / \mathrm{mol}$ higher than for $P$. ponderosa (Table 6). Shrub removal significantly decreased daily integrated WUE for $P$. monophylla (two-way ANOVA, $F_{\text {species }}=31.8, \mathrm{df}=1,24, P<$ $0.001)$.

\section{Survival and conductance of $\mathrm{P}$. ponderosa in shrub- removal expèriments}

We found strong differences among treatments for survival of 2 -yr-old $P$. ponderosa saplings, with $28 \%$ surviving the summer when planted in plots with shrubs removed and none surviving under shrubs and in intershrub spaces (Fig. 3). In contrast to the heavy predation experienced by 4-mo-old seedlings in 1992, there was no sign of herbivory on any of the saplings, and all mortality occurred as saplings dried in place. Corresponding with the strong positive effect of shrub removal on $P$. ponderosa sapling survival was a sig-

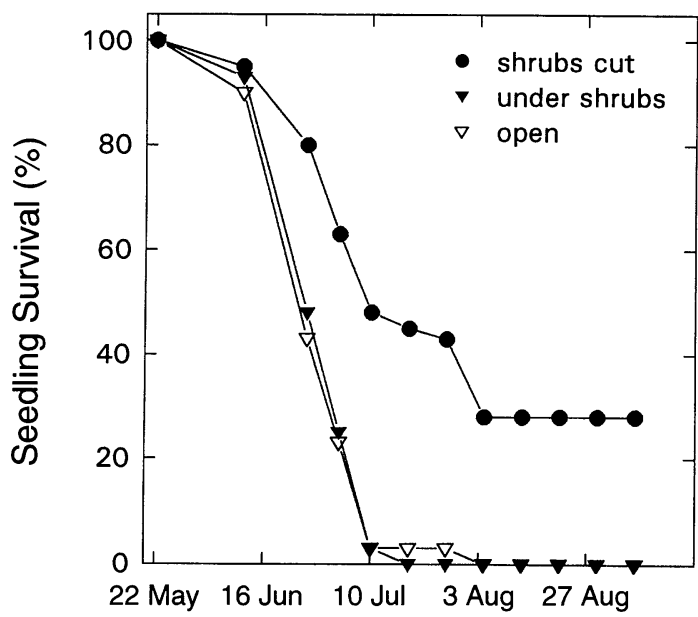

FIG. 3. Survival of 2-yr-old, planted Pinus ponderosa saplings on unaltered andesite under Artemisia tridentata shrubs (under shrubs), in the intershrub spaces (open), and in shrubremoval treatments (shrubs cut). For all treatments, initial $n$ $=40$ saplings nificant increase in conductance (Fig. 4). On 4 June, average conductances of saplings in shrub-removal treatments were $\approx 3$ times greater than those in intershrub spaces or under shrubs. By the end of July, conductance of almost all saplings within the shrub matrix had ceased. Conductance of saplings in the removal plots increased substantially in late July and early August even though no rainfall occurred, suggesting that the roots of surviving saplings may have reached deeper, less transient water sources than surface moisture.

Conductances of older, naturally occurring saplings were generally three to nine times higher than conductances of saplings planted in shrub-removal plots, and, as for planted $P$. ponderosa, shrub removal had strong positive effects on conductances of naturally occurring $P$. ponderosa (Fig. 5). On 4 June, conductances of saplings around which Artemisia and other

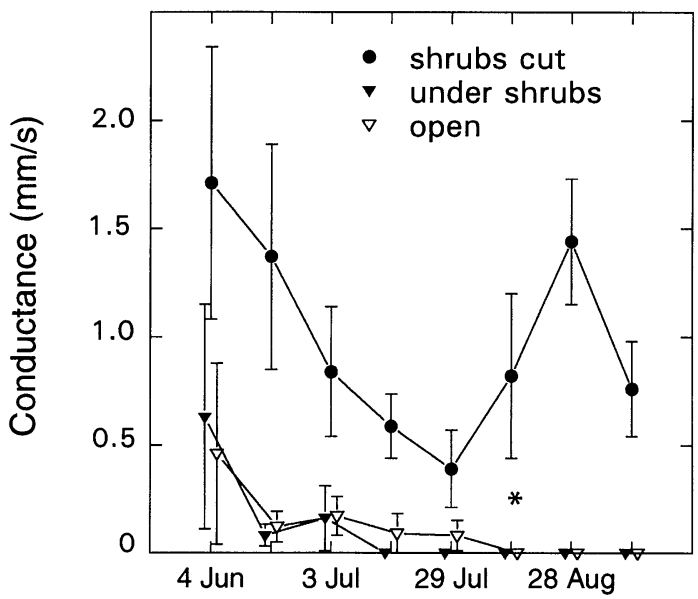

FIG. 4. Leaf conductances of 2-yr-old, planted Pinus ponderosa saplings on unaltered andesite under Artemisia tridentata shrubs (under shrubs), in the intershrub spaces (open), and in shrub-removal treatments (shrubs cut). For all treatments, initial $n=5$ saplings; after 29 July $n<5$ saplings in shrub matrix due to mortality. The asterisk $(*)$ indicates the date at which saplings in the shrub matrix appeared to be dead. Means were significantly higher in the shrub-removal treatment on all dates. 


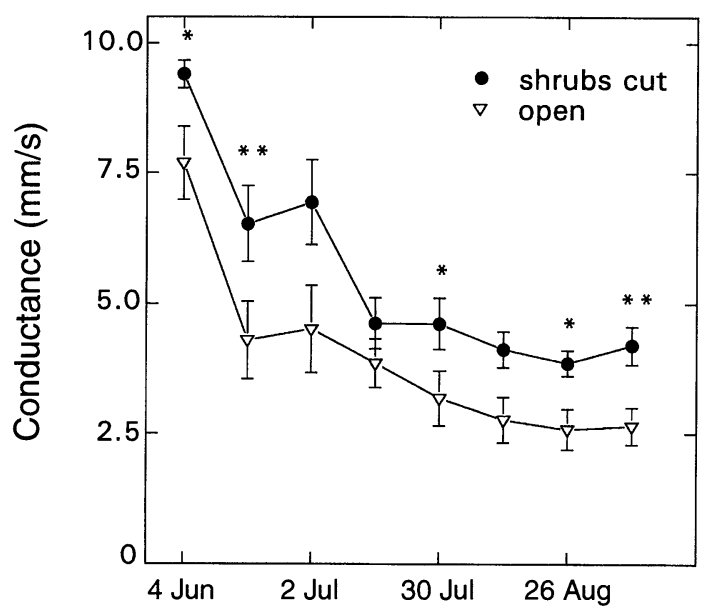

FIG. 5. Leaf conductances of paired $P$. ponderosa saplings on unaltered andesite in plots with Artemisia tridentata and other shrubs removed from a 3-m radius around saplings, and in control plots without shrubs removed. Data show means $\pm 1 \mathrm{SE} ; *$ indicate significantly higher conductances based on pairwise Student's $t$ tests.

shrubs had been removed were $25 \%$ higher than those of the control saplings. Conductances of saplings in the removal treatment were consistently higher throughout the summer and were significantly higher (Student's $t$ test, $P<0.05$ ) on four of the eight sampling days. Competitive intensity did not appear to change substantially with sapling age as differences in conductances between shrub-removal and control saplings were not correlated with sapling size $\left(r^{2}=0.23, P=\right.$ $0.44)$.

Survival of naturally occurring P. monophylla seedlings on altered andesite with imitation nurse plants

On altered andesite, survival of Pinus monophylla seedlings was generally higher with imitation nurse plants than in the open; however, there were differences between north-facing and south-facing sites (Fig. 6). On the north-facing site $84 \%$ of naturally germinating seedlings that were provided with imitation nurse plants survived for $1 \mathrm{yr}$, whereas $68 \%$ of the seedlings in the open survived $\left(\chi^{2}=0.42\right.$, df $\left.=1, P>0.5\right)$. On the south-facing site $35 \%$ of the seedlings under mimic nurse plants survived in comparison to only $10 \%$ in the open; however, the difference between these treatments was only marginally significant $\left(\chi^{2}=2.78\right.$, df $=1, P=0.09)$. All mortality observed in this experiment occurred as seedlings dried in place.

\section{Discussion}

Our first hypothesis, that Artemisia interferes with $P$. ponderosa, was supported by field experiments, but negative effects of Artemisia on $P$. ponderosa appeared to be both indirect and direct. The indirect effect appeared to occur through increased predation on seeds

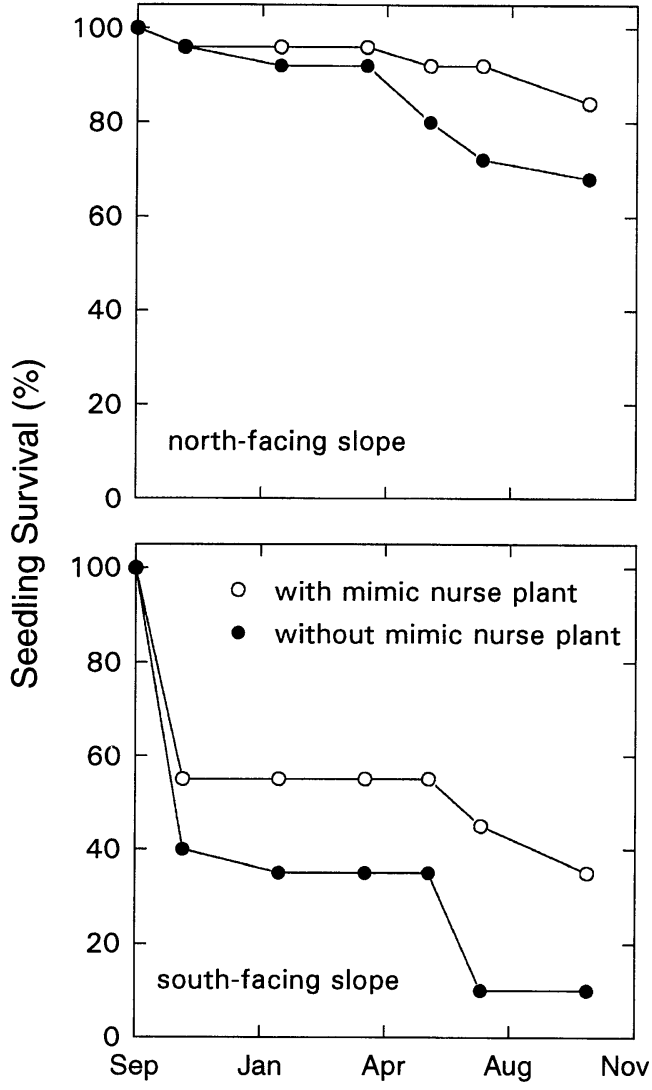

FIG. 6. Survival of naturally germinating Pinus monophylla seedlings on altered andesite under imitation nurse plants and in the open on north- and south-facing slopes. Initial $n=25$ seedlings for each treatment on north-facing slopes, and $n=20$ seedlings on south-facing slopes.

and seedlings on unaltered andesite. We suspect that seedlings were rapidly consumed by small mammals that are dependent on shrubs for cover, and that seedlings germinating on altered andesite were relatively safe because these herbivores avoid open spaces. Potential predators of seeds or seedlings of both pine species include jackrabbits (Lepus californicus), mule deer (Odocoileus hemonius), yellow pine chipmunks (Tamias amoenus), woodrats (Neotoma spp.), and deer mice (Peromyscus maniculatus). The importance of predation on $P$. ponderosa appeared to diminish with age as 2-yr-old saplings were virtually untouched by herbivores (D. J. Moore and R. M. Callaway, personal observation); however, different predation intensities on seedlings and saplings may have been confounded by the different years in which 4-mo-old and 2-yr-old $P$. ponderosa were tested. The use of greenhousegrown, and potentially more palatable, seedlings may have overemphasized the effects of predation. Furthermore, because we did not conduct predator-exclosure experiments, the relative importance of predation in our study remains uncertain.

Artemisia shrubs also competed directly with $P$. pon- 
derosa seedlings and saplings for soil water. Removal of Artemisia increased soil moisture and doubled the daily transpiration and photosynthetic rates of 4-moold $P$. ponderosa seedlings and enhanced the survival and conductance of older, planted saplings. Competition for soil water from Artemisia also reduced the conductance of older, naturally occurring $P$. ponderosa saplings. Direct competitive and indirect predation effects may explain the absence of $P$. ponderosa seedlings and adults on unaltered andesite, and the restriction of this species to shrubless altered andesite. In a similar system in northwestern Mexico, Goldberg $(1982,1985)$ found that competition and high seed predation limited evergreen oaks to hydrothermally altered volcanic rock from which the otherwise dominant drought-deciduous trees were restricted by the nutrientpoor substrate.

An alternative, but not mutually exclusive, hypothesis for the restricted distribution of $P$. ponderosa is that altered andesite, because it was originally derived from hydrothermal activity, stores water differently than unaltered andesite. Curves of water potential vs. percent soil moisture differ between surface soils derived from altered and unaltered andesite (DeLucia et al. 1988). The structure of the underlying rock may also differ, as surface springs emerged on altered andesite near the DRI, Peavine Mt., and lower Virginia Mts. sites in the spring of 1993, following an exceptionally wet winter (R.M. Callaway and D. Moore, personal observations).

Our second hypothesis, that Artemisia facilitates $P$. monophylla, was also supported, and facilitative interactions also appeared to have both direct and indirect components. On unaltered andesite, a much higher proportion of naturally occurring seedlings were under shrub canopies than expected based on shrub cover. Although losses attributed to predation were significantly lower for $P$. monophylla than for $P$. ponderosa in general, shrubs provided indirect facilitation within the shrub matrix by reducing apparent predation. As for $P$. ponderosa, however, our conclusions regarding predation should be considered with caution in the absence of exclosure experiments.

Artemisia also appears to directly enhance survival of $P$. monophylla by favorably altering microclimate. Virtually all $P$. monophylla seedlings on altered andesite or in intershrub spaces eventually died from drought or temperature-related stress if they escaped predation. In contrast, none of the seedlings in the shade of shrubs died due to drought and temperature stress. Fowells (1965) reports that shade is important in the establishment of the similar pinyon species $P$. edulis. Artemisia also has the potential to directly facilitate neighbors via hydraulic lift (Richards and Caldwell 1987, Caldwell and Richards 1989). Shelter provided by Artemisia appears to have a cost: Pinus monophylla seedlings were smaller under shrubs than in the open or where shrubs had been cut, indicating that while the overall affect of Artemisia on survival was positive, the survivors experienced reduced aboveground growth.

Facilitative interactions among other species also appeared to be mediated by a combination of direct and indirect mechanisms. In the Sonoran Desert, the beneficial effect of Cercidium microflorum on the saguaro, Carnegia gigantea, is due to both microclimate amelioration and protection from herbivores (Turner et al. 1966, 1969, Steenberg and Lowe 1969). Callaway (1992) found that positive effects of shrubs on Quercus douglasii were mediated by a combination of protection from predators and shade from shrub canopies. Valiente-Banuet and Ezcurra (1991) compared the relative importance of shade vs. protection from predation in the nurse-plant relationship between Neobuxbaumia tetetzo, a columnar cactus, and Mimosa luisana in the Viscaino Desert and the Gran Desierto de Altar in Mexico. They found that protection from predation improved survival, but that long-term survival occurred only when shade was provided.

Our third hypothesis, that $P$. monophylla is restricted from outcrops of altered andesite by the absence of Artemisia rather than by substrate characteristics, was supported by data that emphasized the general importance of nurse plants for $P$. monophylla, but not by field experiments using imitation nurse plants. Pinus monophylla has a high tolerance for altered andesite in the greenhouse (DeLucia et al. 1989), so if it requires the positive effects provided by Artemisia, the absence of Artemisia may explain the absence of $P$. monophylla adults on altered andesite.

Interspecific differences in our estimations of predation may have been due to dissimilar morphologies and chemical components of seeds and seedlings. The seeds of $P$. monophylla are dispersed by animals and are much larger than the wind-dispersed seeds of $P$. ponderosa. Larger seeds both are likely to be more attractive to some predators and have a higher probability of being found. Vander Wall $(1992,1993)$ documented the importance of chipmunk dispersal of $P$. jefferyi seeds, indicating that predation rates on yellow pines may be high. On the other hand, the leaves of the $P$. monophylla seedlings in our experiments were tougher, had sharper leaf tips, and appeared much more aromatic and resin-filled than those of $P$. ponderosa. These characteristics may have deterred predation on $P$. monophylla seedlings relative to $P$. ponderosa.

The mechanisms by which Artemisia directly facilitates $P$. monophylla but competes with $P$. ponderosa are not clear; however, both interactions have been attributed to the conservative water-use strategies of these pines (DeLucia et al. 1988, Drivas and Everett 1989). DeLucia et al. (1988) maintained that Artemisia, with relatively low WUEs and high transpiration rates, outcompeted the water-conservative $P$. ponderos $a$ by using soil water before the latter could. Pinus monophylla, however, has even higher WUEs than $P$. pon- 
derosa (Table 6 and DeLucia et al. 1988, 1989), yet it is facilitated by Artemisia. Perhaps conservative water relations conferred a disadvantage for both $P$. ponderosa and $P$. monophylla when growing with Artemisia, but only $P$. monophylla was conservative enough to withstand the long periods of drought induced by $A r$ temisia during the seedling stage. Jaindl et al. (1993) found that $P$. monophylla did not displace another Great Basin shrub, Cercocarpus ledifolius, as it appears to do to many other shrubs. As for Artemisia and $P$. ponderosa (see DeLucia et al. 1988), rapid transpiration and depletion of soil moisture by Cercocarpus were cited as the factors preventing invasion by $P$. monophylla. Predawn water potentials of Cercocarpus (Jaindl et al. 1993) were not lower than those of $\mathrm{Ar}$ temisia (DeLucia et al. 1988), so why the low growth rates and high WUE of $P$. monophylla would promote its competitive exclusion by Cercocarpus but also its facilitation by Artemisia is unclear. DeLucia et al. (1989) speculated that lower growth and respiration rates also may confer higher probabilities of $P$. monophylla surviving extended periods of low soil water availability than $P$. ponderosa. We suspect that the comparatively thick leaves and stems of $P$. monophylla were more susceptible to overheating, high respiration losses, and photoinhibition when stomata were closed and seedlings were exposed to full sun, than those of $P$. ponderosa. Differences in root architecture between $P$. ponderosa and $P$. monophylla may also have played an important role in their interactions with Artemisia.

Our experimental results support a number of studies in which spatial associations or species variation with plot age have been cited as evidence for the facilitative effect of Artemisia on P. monophylla or P. edulis (Phillips 1909, Drivas and Everett 1989, Weldon et al. 1990). Shrub facilitation of pinyon pine appears to affect patterns of invasion and replacement in the Great Basin (Woodbury 1947, Blackburn and Tueller 1970, Barney and Frischknecht 1974, Tausch et al. 1981, Eddleman and Jaindl 1991).

Considered together, our results suggest that the absence of Artemisia on altered andesite created refuges for $P$. ponderosa because of reduced competition from Artemisia, but created unfavorable habitat without the biotic safe-sites required by $P$. monophylla. Whether Artemisia competed with or facilitated neighboring pine species appeared to depend on subtle differences in palatability to predators, gas exchange, thermal tolerances, and responses to light.

\section{ACKNOWLEDGMENTS}

We thank Will Pyle and Craig Sabraw for field work. We also thank the Desert Research Institute, U.S. Forest Service, and the Bureau of Land Management for access to lands in their care. Hal Klieforth provided much of the climate data. This project was funded by U.S.D.A. grant number 9137101-6724, awarded to E. H. DeLucia and W. H. Schlesinger.

\section{LiTERATURE CiTED}

Barney, M. A., and N. C. Frischknecht. 1974. Vegetation changes following fire in the pinyon-juniper type of westcentral Utah. Journal of Range Management 27:91-96.

Bertness, M. D., and R. M. Callaway. 1994. Positive interactions in communities. Trends in Ecology and Evolution 9:191-193.

Bertness, M. D., and S. W. Shumway. 1993. Competition and facilitation in marsh plants. American Naturalist 142: 718-724.

Billings, W. D. 1950. Vegetation and plant growth as affected by chemically altered rocks in the western Great Basin. Ecology 31:62-74.

Blackburn, W. H., and P. T. Tueller. 1970. Pinyon and juniper invasion in black sagebrush communities in east central Nevada. Ecology 51:841-848.

Caldwell, M. M., and J. H. Richards. 1989. Hydraulic lift: water efflux from upper roots improves effectiveness of water uptake by deep roots. Oecologia 79:1-5.

Callaway, R. M. 1992. Effect of shrubs on recruitment of Quercus douglasii and Quercus lobata in California. Ecology 73:2118-2128.

. 1994. Facilitating and interfering effects of Arthrocnemum subterminale on winter annuals in a California salt marsh. Ecology 75:681-686.

Callaway, R. M., and F. W. Davis. 1993. Vegetation dynamics, fire, and the physical environment in coastal central California. Ecology 74:1567-1578.

Callaway, R. M., E. H. DeLucia, and W. H. Schlesinger. 1994. Biomass allocation of montane and desert Ponderosa pine: an analog for climate change. Ecology 75:1474-1481.

Callaway, R. M., N. M. Nadkarni, and B. E. Mahall. 1991. Facilitating and interfering effects of Quercus douglasii on understory productivity in central California. Ecology 72: 1484-1499.

Cottam, G., and J. T. Curtis. 1956. Use of distance measurements in phytosociological sampling. Ecology 37:451460.

DeLucia, E. H., and S. A. Heckathorn. 1989. The effect of soil drought on water-use efficiency in contrasting Great Basin Desert and Sierran montane species. Plant Cell and Environment 12:935-940.

DeLucia, E. H., and W. H. Schlesinger. 1989. Resource-use efficiency and drought tolerance in adjacent Great Basin and Sierran plants. Ecology 72:51-58.

DeLucia, E. H., W. H. Schlesinger, and W. D. Billings. 1988. Water relations and the maintenance of Sierran conifers on hydrothermally altered rock. Ecology 69:303-311.

DeLucia, E. H., W. H. Schlesinger, and W. D. Billings. 1989. Edaphic limitations to growth and photosynthesis in Sierran and Great Basin vegetation. Oecologia 78:184-190.

Drivas, E. P., and R. L. Everett. 1989. Water relations characteristics of competing singleleaf pinyon seedlings and sagebrush nurse plants. Forest Ecology and Management 23:27-37.

Eddleman, L. E., and R. G. Jaindl. 1991. Great Basin National Park vegetation analysis. Great Basin National Park, Baker, Nevada, USA.

Everett, R. L., S. H. Sharrow, and R. O. Meeuwig. 1983. Pinyon-juniper woodland understory distribution patterns and species associations. Bulletin of the Torrey Botanical Club 110:454-463.

Fowells, H. A. 1965. Silvics of forest trees of the United States. U.S. Department of Agriculture Handbook 271, Washington, D.C., USA.

Gianella, V. P. 1936. Geology of the Silver City district and the southern portion of the Comstock Lode, Nevada. University of Nevada Bulletin 30(9).

Goldberg, D. E. 1982. The distribution of evergreen and deciduous trees relative to soil type: an example from the 
Sierra Madre, Mexico, and a general model. Ecology 63: 942-951

1985. Effects of soil pH, competition, and seed predation on the distributions of two tree species. Ecology 66: 503-511.

Hutsinpiller, A. 1988. Discrimination of hydrothermal alteration mineral assemblages at Virginia City, Nevada using the airborne imaging spectrometer. Remote Sensing of Environment 24:53-66.

Jaindl, R. G., P. S. Doescher, and L. E. Eddleman. 1993. Influence of water relations on the expansion of Pinus monophylla into adjacent Great Basin communities in the central Great Basin. Forest Science 39:629-643.

Pearcy, R. W., E.-D. Schultze, and R. Zimmerman. 1992. Measurement of transpiration and leaf conductance. Pages 137-160 in R. W. Pearcy, J. Ehleringer, H. A. Mooney, and P. W. Rundel, editors. Plant physiological ecology: field methods and instrumentation. Chapman and Hall, New York, New York, USA.

Phillips, F. J. 1909. A study of pinyon pine. Botanical Gazette 48:216-223.

Richards, J. R., and M. M. Caldwell. 1987. Hydraulic lift: substantial nocturnal water transport between soil layers by Artemisia tridentata roots. Oecologia 73:486-489.

Schlesinger, W. H., E. H. DeLucia, and W. D. Billings. 1989. Nutrient-use efficiency of woody plants on contrasting soils in the western Great Basin, Nevada. Ecology 70:105-113.

Silander, J. A., and J. Antonovics. 1982. Analysis of interspecific interactions in a coastal plant community-a perturbation approach. Nature 298:557-560.
Smith, W. K. 1980. Importance of aerodynamic resistance to water use efficiency in three conifers under field conditions. Plant Physiology 65:132-135.

Steenberg, W. F., and C. H. Lowe. 1969. Critical factors during the first year of life of the saguaro (Cereus giganteus) at Saguaro National Monument. Ecology 50:825-834.

Tausch, R. J., N. E. West, and A. A. Nabi. 1981. Tree age and dominance patterns in Great Basin pinyon-juniper woodland. Journal of Range Management 34:259-264.

Turner, R. M., S. M. Alcorn, and G. Olin. 1969. Mortality of transplanted saguaro seedlings. Ecology 50:835-844.

Turner, R. M., S. M. Alcorn, G. Olin, and J. A. Booth. 1966. The influence of shade, soil, and water on saguaro seedling establishment. Botanical Gazette 127:95-102.

Valiente-Banuet, A., and E. Ezcurra. 1991. Shade as a cause of the association between the cactus Neobuxbaumia tetetzo and the nurse plant Mimosa luisana in the Tehuacan Valley, Mexico. Journal of Ecology 79:961-971.

Vander Wall, S. B. 1992. The role of animals in dispersing a "wind-dispersed" pine. Ecology 73:614-621.

. 1993. Cache site selection by chipmunks (Tamias spp.) and its influence on the effectiveness of seed dispersal in Jeffery pine (Pinus jefferyi). Oecologia 96:246-252.

Weldon, C. W., W. L. Slauson, and R. T. Ward. 1990. Spatial pattern and interference in pinon-juniper woodlands of northwest Colorado. Great Basin Naturalist 50:313-319.

Wilkinson, L. 1990. SYSTAT: the system for statistics. SYSTAT, Evanson, Illinois, USA.

Woodbury, A. M. 1947. Distribution of pygmy conifers in Utah and northeastern Arizona. Ecology 28:113-126. 